\title{
INDOOR AIR QUALITY MODELLING ON UNIVERSITY BUILDINGS IN TABASCO, MEXICO
}

\author{
ELIZABETH MAGAÑA-VILLEGAS, SERGIO RAMOS-HERRERA, IRVING IVÁN SALVADOR-TORRES, \\ JESÚS MANUEL CARRERA-VELUETA \& RAÚL GERMÁN BAUTISTA-MARGULIS \\ Universidad Juárez Autónoma de Tabasco, México
}

\begin{abstract}
Indoor air quality in academic areas has become of vital importance in high educational institutions worldwide. This is very important since students spend a substantial time in such common areas. The current objective of this investigation was to evaluate the air pollutant levels in two common areas (coffee shop and library) at the Juarez Autonomous University of Tabasco, Mexico. The study consisted in monitoring carbon monoxide $(\mathrm{CO})$ and particulate material $\left(\mathrm{PM}_{10}\right)$ concentration regarding the carbon dioxide $\left(\mathrm{CO}_{2}\right)$, temperature $(\mathrm{T})$ and relative humidity $(\mathrm{RH})$. From the indoor air measurements, lineal regression models were also obtained to explain the $\mathrm{CO}_{2}, \mathrm{CO}$ and $\mathrm{PM}_{10}$ behaviour as a function of the temperature and relative humidity. The hourly average of $\mathrm{PM}_{10}, \mathrm{CO}$ and $\mathrm{CO}_{2}$ were computed to evaluate the air quality and indoor comfort level based on EPA, WHO and ASHRAE (the American Society of Heating, Refrigerating and Air-Conditioning Engineers) regulations. At the coffee shop, the $\mathrm{CO}$ concentration levels were found to be exceeded according to the air quality standards established by WHO. For both library and coffee shop, the mean hourly values of $\mathrm{CO}_{2}$ and temperature exceeded the maximum values recommended by ASHRAE as comfort levels. Concerning the relative humidity in the library, values of $60 \%$ were recorded exceeding the maximum levels established by ASHRAE. Finally, the current results revealed that temperature and relative humidity played an important role for bacteria growth, indicating its presence for indoor ambient spaces, under similar ambient conditions. Keywords: indoor air quality, atmospheric pollution, lineal regression models.
\end{abstract}

\section{INTRODUCTION}

In the last three decades the public has become more aware of indoor air pollution worldwide. In this context, it has become an important public health issue since most urban population spend more than $80 \%$ of their time indoors [1]-[4]. Field studies of human exposure to air pollutants indicate that indoor air levels of many pollutants may be two to five times, and, occasionally, more than one hundred times higher than outdoor levels [5]-[7]. The main factors affecting air quality in enclosed environments can be described as: 1) inadequate ventilation due to insufficient clean air supply, high recirculation levels, poor air distribution by a ventilation system, lack of maintenance or incorrect design of the filter systems and, either extreme or fluctuating climate conditions; 2) contaminants from indoor sources like combustion gases releasing inorganic gaseous pollutants, formaldehyde, suspended particulates and other toxic chemicals (i.e., pesticides, tobacco and cleaning products); 3) contaminants from outdoor sources like combustion gases generated by vehicles and industrial processes, asphalt used in construction works and maintenance, among others [8]. At this point, it is worth mentioning that the particulate material has also been recognized as a significant health problem.

In this context, the World Health Organization has described "The Sick Building Syndrome" (SBS) as an excessive repetition of one or more syndromes to those people inside a workplace [9]. The symptoms associated to SBS can be moderate and affect the eyes, nose, throat, head and skin. The type and affectation of the symptoms vary depending on the environmental factors as well as the patient, sex and atopy. Research works on SBS have shown that physiologic and psychologic factors of the people are closely related to relative 
humidity and temperature perception capability, except for indoor concentration changes of aerosols. However, indoor air quality in enclosed spaces is known to be strongly influenced by indoor sources (i.e. fry, roast, toast, and smoke), the use of oven, candles and heating systems could also increase the concentration levels of submicron particles up to five times; while $\mathrm{PM}_{2.5}$ may reach up to 3, 30 and 90 times higher than those found for tobacco, frying and roasting grill, respectively [10].

Common areas, like university libraries and coffee shops, are buildings with unique characteristics. In developing countries, the most important air quality indoor source of carbon monoxide exposition are emissions from oven devices, fuel-biomass burning and tobacco smoke [11]. Carbon monoxide is known to be a relatively non-reactive gas at ambient conditions that cannot be absorbed by construction materials or filters from the ventilation systems [12]. The library, on the other hand, is an enclosed space with reduced ventilation favouring the carbon dioxide build-up. Moreover, employees remaining in this type of enclosures for long periods of time have demonstrated a very strong correlation between high concentration of air pollutants (i.e., $\mathrm{CO}_{2}$, MP and VOCs) and associated symptoms of SBS to library users [13]-[15]. Consequently, indoor air quality in restaurants and libraries has become of vital importance in high educational institutions since students spend a substantial time in both places. Unfortunately, both students and teacher's schools are not aware of the presence of indoor air pollutants. In this respect, few studies have been performed to characterize and compare the indoor levels of atmospheric contaminants.

In order to better understand the relationship between indoor air quality and health effects to the student population within the university buildings, the air quality was quantified by relating the $\mathrm{CO}, \mathrm{PM}_{10}$ and comfort levels regarding the $\mathrm{CO}_{2}$, temperature and relative humidity. In this context, lineal regression models were obtained to explain the $\mathrm{CO}_{2}, \mathrm{CO}$ and $\mathrm{PM}_{10}$ behaviour as a function of the indoor temperature and relative humidity.

\section{MATERIALS AND METHODS}

\subsection{Area of study}

The current study was undertaken at the "Universidad Juarez Autónoma de Tabasco" (UJAT) - "División Académica de Ciencias Biológicas" (DACBiol) which is located at Tabasco, Mexico. In this area, the weather is humid-warm with heavy rainfall in summer, annual average temperature of $33.6^{\circ} \mathrm{C}$, maximum average temperature of $40^{\circ} \mathrm{C}$ in May, and minimum average temperature of $21.7^{\circ} \mathrm{C}$ during December and January. The annual pluvial precipitation is about $2237 \mathrm{~mm}$, with predominant winds at the north-east direction and frequent rain periods in October and March (Fig. 1).

\subsection{Data survey}

The data monitoring was carried out for two common indoor locations at the DACBiol: library and coffee shop. The sampling period took place from the 7th to 18th November 2016, each place was monitored for a week (Monday to Friday) at three different times (8:00-10:00 $\mathrm{h} ; 12: 00-14: 00 \mathrm{~h}$ and 16:00-18:00 h). Concentrations of air pollutants (PM10, CO and CO2) were measured with two particle counters Blue-DT9880 (ISO 21501) and two portable analyzers model EVM-07.

Indoor temperature $(\mathrm{T})$ and relative humidity $(\mathrm{RH})$ were also measured at the monitoring intervals of 1 minute. 


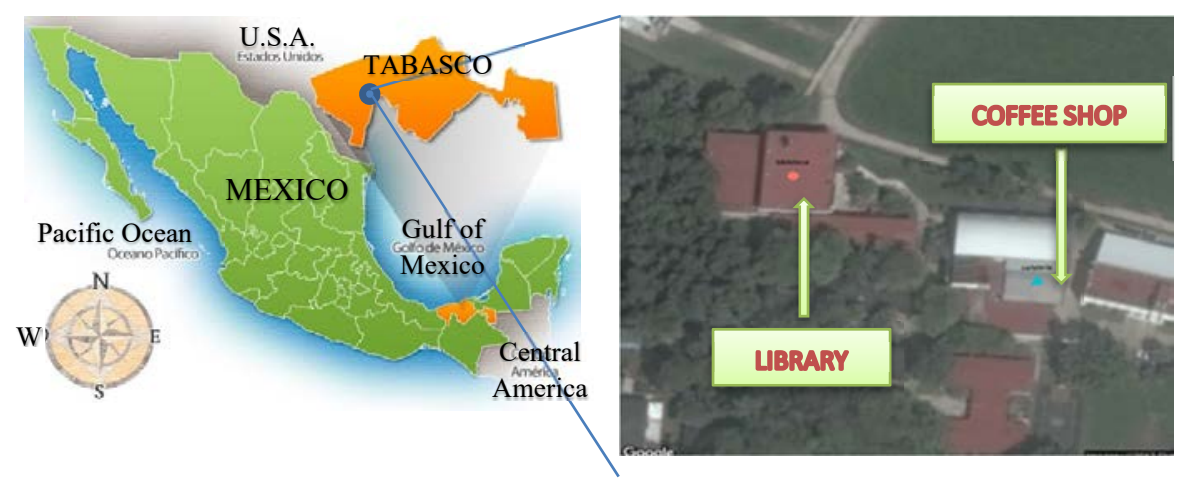

Figure 1: Area of study at the university facility (UJAT-DACBiol).

The particle counter Blue-DT9880 is based on the determination of particle size distribution via light scattering, having continuous counting for particulate material in the range of $0.3-0.5 \mu \mathrm{m}, 0.5-1 \mu \mathrm{m}, 1-2.5 \mu \mathrm{m}, 2.5-5 \mu \mathrm{m}, 5-10 \mu \mathrm{m}$ and $>10 \mu \mathrm{m}$, operating at $2.83 \mathrm{l} / \mathrm{min}$. In order to avoid overloading the optical system and extend the useful life of the instruments, the pump was turned on during 1 min within each period of 2 min and during 1 $\mathrm{h}$ in each monitoring test. Good statistical data resulted for the two particle counters. Counter 1 was placed next to the EVM-07 equipment near the entrance, while counter 2 was placed in the middle of the ambient indoor space.

\subsection{Statistical analysis}

The initial measurements of the various indoor ambient parameters were registered on a database. Thereafter, a number of average air pollutant concentrations were estimated at 5 min, $10 \mathrm{~min}, 15 \mathrm{~min}, 20 \mathrm{~min}, 30 \mathrm{~min}$ and $1 \mathrm{~h}$. The hourly average of PM10 and CO were used to evaluate the air quality based on EPA and WHO regulations. The hourly average of $\mathrm{CO}_{2}$ was employed to evaluate the indoor comfort level by using the ASHRAE, EPA and WHO criteria. Likewise, the correlation of the indoor air pollutants with temperature and relative humidity was analyzed.

The average values, with $\Delta \mathrm{t} \leq 30 \mathrm{~min}$, were employed to analyze the average time which, in turn, gives the maximum correlation and adjust either lineal regression models or best probability distribution of the $\mathrm{CO} 2, \mathrm{CO}$ and PM10 concentrations. The statistical test of Kolmorogov-Smirnov was found to be the best fit for the type of distribution with respect to the current data [16]. The particle number data registered with the Blue-DT9880 equipment and the $\mathrm{PM}_{10}$ recorded with the EVM-07 analyzer were used to calibrate a lineal regression model (equation 1). Such a model was obtained to predict the $\mathrm{PM}_{10}$ concentration from the sampling of the particle number. The model performance was assessed by the crossed validation technic (CVT) with $\mathrm{k}=10$ groups and $\mathrm{r}=10$ repetitions. This technic consisted in dividing randomly the data of two groups: a) with $80 \%$ of the original data (training group, TG1) and, b) with the remaining 20\% (test group, TG2). El TG1 was used to validate the model. As an error measure of the model performance at this stage, the root mean square error (RMSE, equation 2) and their corresponding average values were estimated for each repetition in the CVT. Therefore, the model was created to predict the PM10 concentration and compared to the observed values of the TG2. At this stage, it is worth mentioning that the statistical analysis was performed with the R programme. 


$$
\begin{aligned}
& y=\beta_{o}+\beta_{1} x+\varepsilon, \\
& R M S E=\sqrt{\frac{1}{n} \sum_{i=1}^{n}\left(\hat{y}_{i}-y_{i}\right)^{2} .}
\end{aligned}
$$

\section{RESULTS AND DISCUSSION}

\subsection{Air quality}

The hourly concentration of $\mathrm{CO}$ and $\mathrm{PM}_{10}$ recorded in the library and coffee shop is shown in Fig. 2. The $\mathrm{CO}$ concentration varied from 2 to $51 \mathrm{ppm}$ and 0 to $6 \mathrm{ppm}$ in the coffee shop and library, respectively. The $\mathrm{PM}_{10}$ concentration ranged from 13 to $412 \mu \mathrm{g} / \mathrm{m}^{3}$ in the coffee shop and 10 to $47 \mu \mathrm{g} / \mathrm{m}^{3}$ at the library.

From these results, the indoor air quality was found to be poor in the coffee shop for the $\mathrm{CO}$ and $\mathrm{PM}_{10}$ concentrations according to the maximum permissible levels (MPL) established elsewhere [12]. The coffee shop area is a crowded place where the cooking activities affect the air quality negatively. This area is usually enclosed but equipped with air conditioning, however, the mixing conditions were not homogeneous. A poor indoor air quality was obtained at the coffee shop, up to 10 times baseline, when preparing the food service [17], [18].
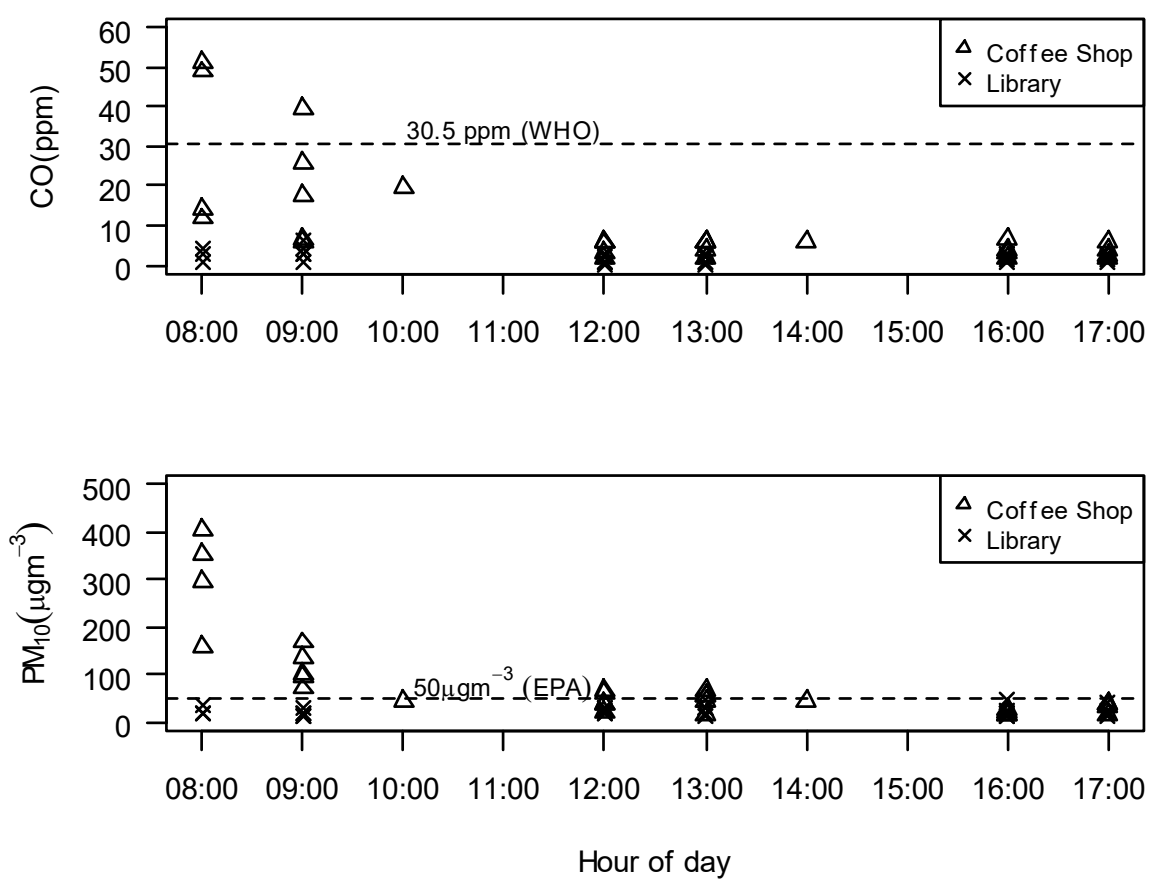

Figure 2: Hourly concentrations of $\mathrm{CO}$ and $\mathrm{PM}_{10}$. 
Furthermore, it was observed that $\mathrm{PM}_{10}$ concentration increased between 2 and 8 times when operating an internal source in both places. However, no significant effects were seen while using any external source.

Fig. 3 shows the hourly concentration of $\mathrm{CO}_{2}$ for both buildings, while the mean hourly concentrations as a function of indoor temperature and relative humidity can be appreciated in Fig. 4. In this context, the $\mathrm{CO}_{2}$ concentrations were measured between 1066 and $2935 \mathrm{ppm}$ in the coffee shop; whilst the library ranged between 967 and 2,322 ppm. For the temperature values, the coffee shop was found to be in the range of 25.3 and $29.7^{\circ} \mathrm{C}$, while the library recorded between 24.8 and $26.7^{\circ} \mathrm{C}$. For relative humidity, values of $51-62 \%$ and $55.4-69.0 \%$ were found at the coffee shop and library, respectively.

In relation with the comfort parameters, three main aspects contributed most to the changing $\mathrm{CO}_{2}$ levels in the studied buildings: 1) variable occupation, 2) population growth and 3) insufficient fresh air supply [19], [20]. Relative humidity was found to be in optimum range according to Gallo [21]. From this work, it was also showed that $60-90 \% \mathrm{RH}$ can lead to spores formation and cause documents alterations, favouring bacteria growth. In addition, aero-bacteria can be easily developed at temperatures between 25 and $38^{\circ} \mathrm{C}$ [22]. Under similar ambient conditions, the current results revealed that temperature and relative humidity played an important role for bacteria growth, indicating its presence for indoor ambient enclosures.

For the main indoor air pollutants $\left(\mathrm{CO}_{2}, \mathrm{CO}\right.$ and $\left.\mathrm{PM}_{10}\right)$ considered in the current work, the highest concentration tendency was observed in the library during the morning and the lowest for the afternoon. In this respect, $\mathrm{CO}$ and $\mathrm{PM}_{10}$ concentrations were seen to remain steady during the morning; nevertheless, an increase of $\mathrm{CO}_{2}$ concentration was observed from the morning hours to the afternoon.

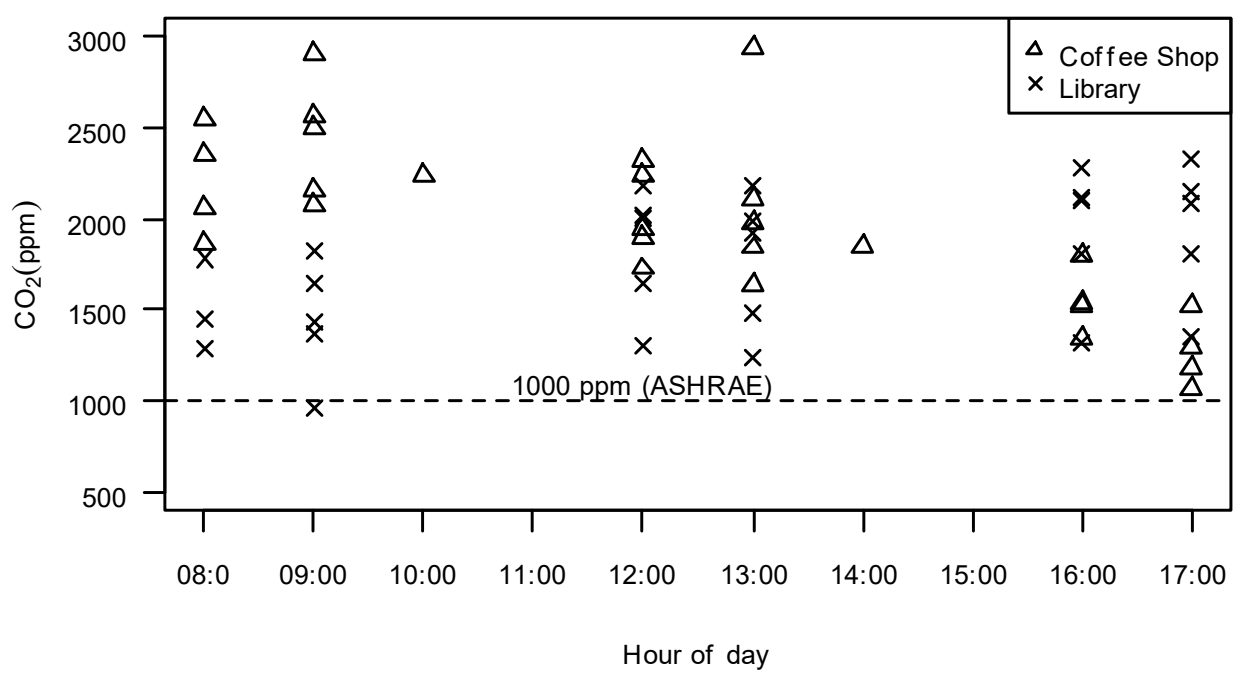

Figure 3: Hourly concentration of $\mathrm{CO}_{2}$. 

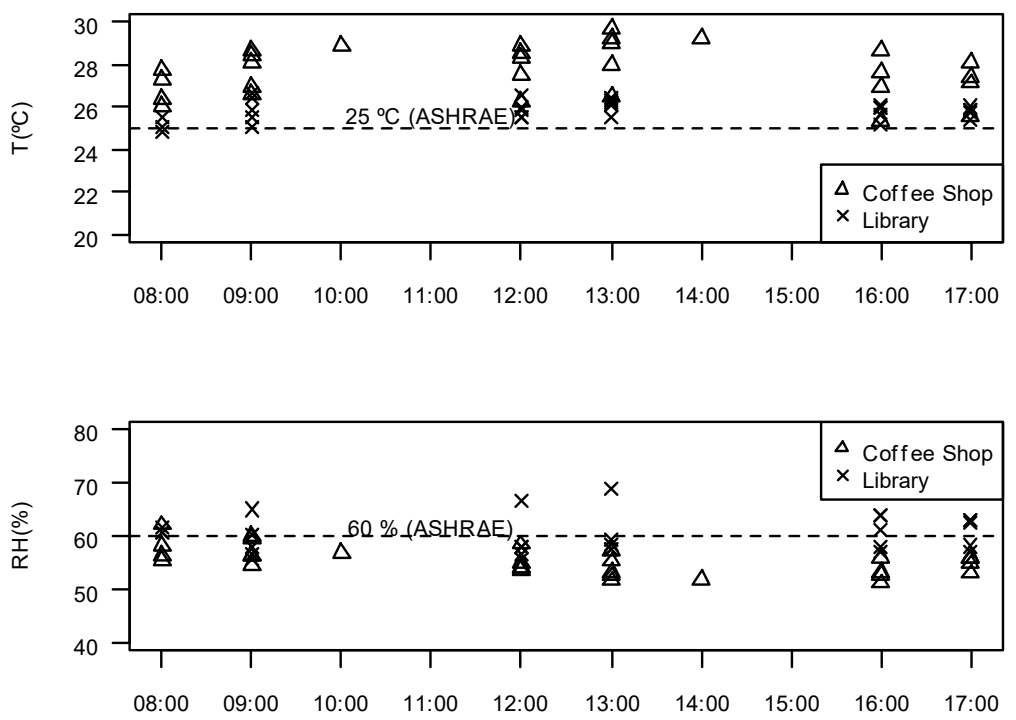

Hour of day
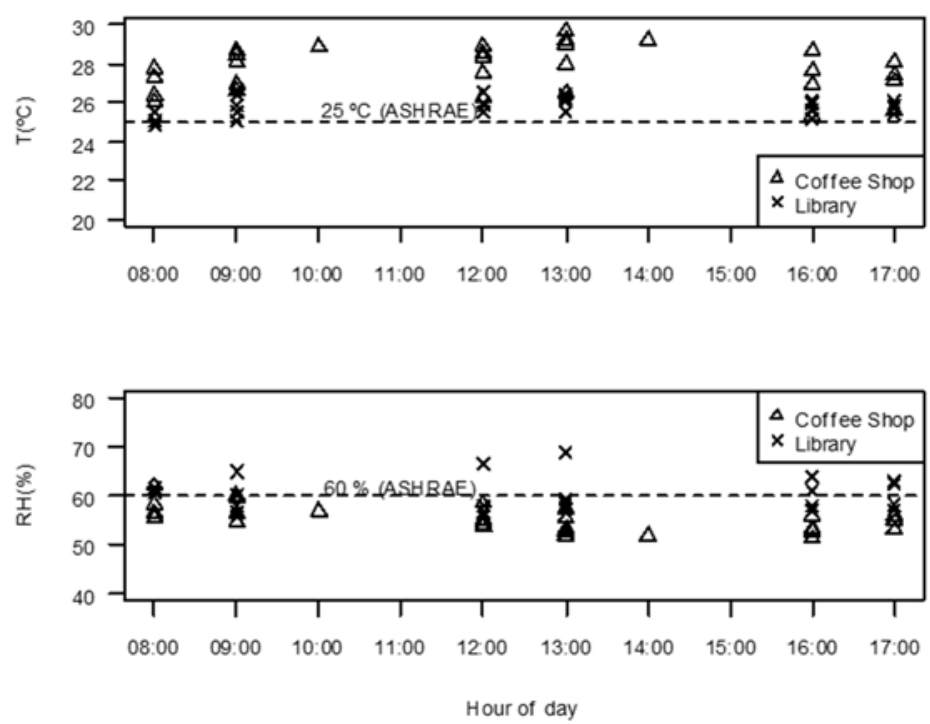

Figure 4: Hourly behaviour of temperature (T) and relative humidity (RH).

Table 1 shows the correlation coefficients of Pearson and Spearman for the hourly level of the three indoor air pollutants and their behaviour with respect to temperature and relative humidity. For the studied air pollutants and relative humidity values, the only significant correlation was found to be in the coffee shop. However, the fitted regression models only explained up to $55 \%$ of the observed variability for the $\mathrm{CO}$ data, $29 \%$ for the $\mathrm{CO}_{2}$ data and $13 \%$ for the $\mathrm{PM}_{10}$. 
Table 1: Correlation coefficients of hourly mean values.

\begin{tabular}{ccccc}
\hline ID & & $\mathrm{PM}_{10}$ & $\mathrm{CO}$ & $\mathrm{CO}_{2}$ \\
\hline \multirow{2}{*}{ Coffee shop } & $\mathrm{RH}$ & $0.41^{*}\left(0.45^{*}\right)$ & $0.69^{*}\left(0.50^{*}\right)$ & $0.58^{*}\left(0.63^{*}\right)$ \\
& $\mathrm{T}$ & $-0.33(-0.19)$ & $0.12(0.28)$ & $0.26(0.17)$ \\
Library & $\mathrm{RH}$ & $0.23(0.04)$ & $0.12(0.14)$ & $-0.13(-0.12)$ \\
& $\mathrm{T}$ & $0.12(0.22)$ & $-0.27(-0.26)$ & $0.34(0.34)$ \\
\hline
\end{tabular}

In order to analyze the correlations among the variables at different average times, low but significant correlations $(r<0.4)$ were estimated for the indoor ambient parameters. Correlation coefficients can be seen in Table 2 at different average times. Nevertheless, the dispersion graphics did not show a clear tendency, reason by which a distribution probability of the mean concentration during 15 minutes was fitted (Fig. 5). This period of time was setup based on the WHO regulations for average exposition times of 15 minutes subjected to occur for maximum expositions in the short time, for example, a poor ventilated oven having $\mathrm{CO}$ and $\mathrm{CO}_{2}$ [12]. The $\mathrm{PM}_{10}$ were fitted to a $\log$ normal distribution $(\mu=4.0, \sigma=0.98)$, while the $\mathrm{CO}$ was not fitted to any distribution and the $\mathrm{CO}_{2}$ was fitted to a normal distribution $(\mu=$ 2014.5, $\sigma=473.8)$.

Table 2: Correlations at different mean times in the coffee shop.

\begin{tabular}{llllllllllll}
\hline Coffee shop & \multicolumn{2}{c}{$5 \mathrm{~min}$} & \multicolumn{2}{c}{$10 \mathrm{~min}$} & \multicolumn{2}{c}{$15 \mathrm{~min}$} & \multicolumn{2}{c}{$20 \mathrm{~min}$} & \multicolumn{2}{c}{$30 \mathrm{~min}$} \\
\hline Parameter & $\mathrm{T}$ & $\mathrm{RH}$ & \multicolumn{1}{c}{$\mathrm{T}$} & $\mathrm{RH}$ & $\mathrm{T}$ & $\mathrm{RH}$ & $\mathrm{T}$ & $\mathrm{RH}$ & $\mathrm{T}$ & $\mathrm{RH}$ \\
$\mathrm{PM}_{10}$ & - & 0.45 & - & 0.45 & - & 0.46 & - & 0.44 & - & 0.48 \\
& 0.3 & $*$ & 0.38 & $*$ & 0.38 & $*$ & 0.37 & $*$ & 0.35 & $*$ \\
$\mathrm{CO}$ & $8^{*}$ & & $*$ & & $*$ & & $*$ & & $*$ & \\
& - & 0.68 & 0.06 & 0.68 & 0.03 & 0.69 & 0.05 & 0.66 & 0.04 & 0.71 \\
& 0.0 & $*$ & & $*$ & & $*$ & & $*$ & & $*$ \\
$\mathrm{CO}_{2}$ & 5 & & & & & & & & & \\
& - & 0.63 & 0.26 & 0.61 & 0.26 & 0.60 & 0.24 & 0.58 & 0.27 & 0.59 \\
& 0.2 & $*$ & $*$ & $*$ & $*$ & $*$ & $*$ & $*$ & & $*$ \\
& $5 *$ & & & & & & & & & \\
\hline
\end{tabular}

${ }^{*}$ Value of $\mathrm{p}<0.05$
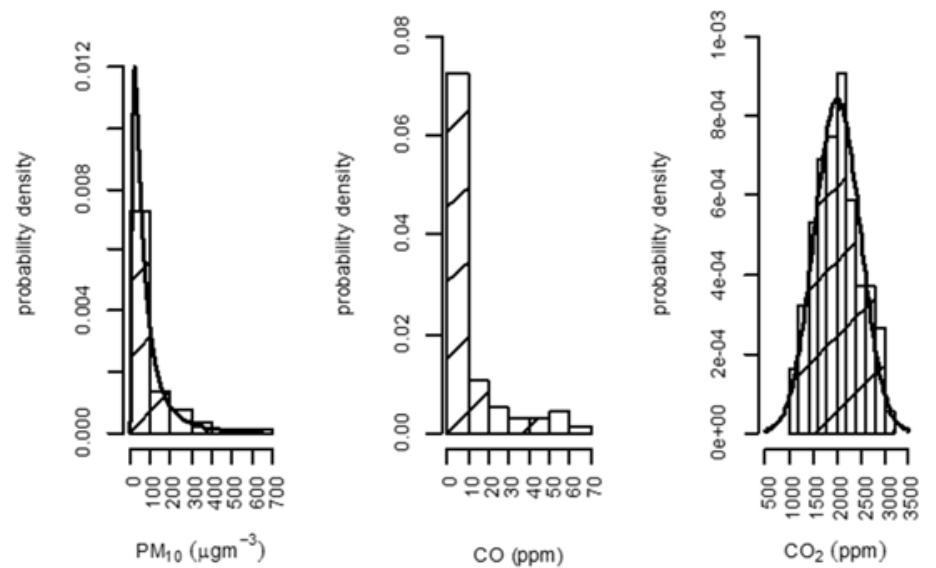

Figure 5: Histograms and probability distributions of $\mathrm{PM}_{10}, \mathrm{CO}$ and $\mathrm{CO}_{2}$ in the coffee shop. 

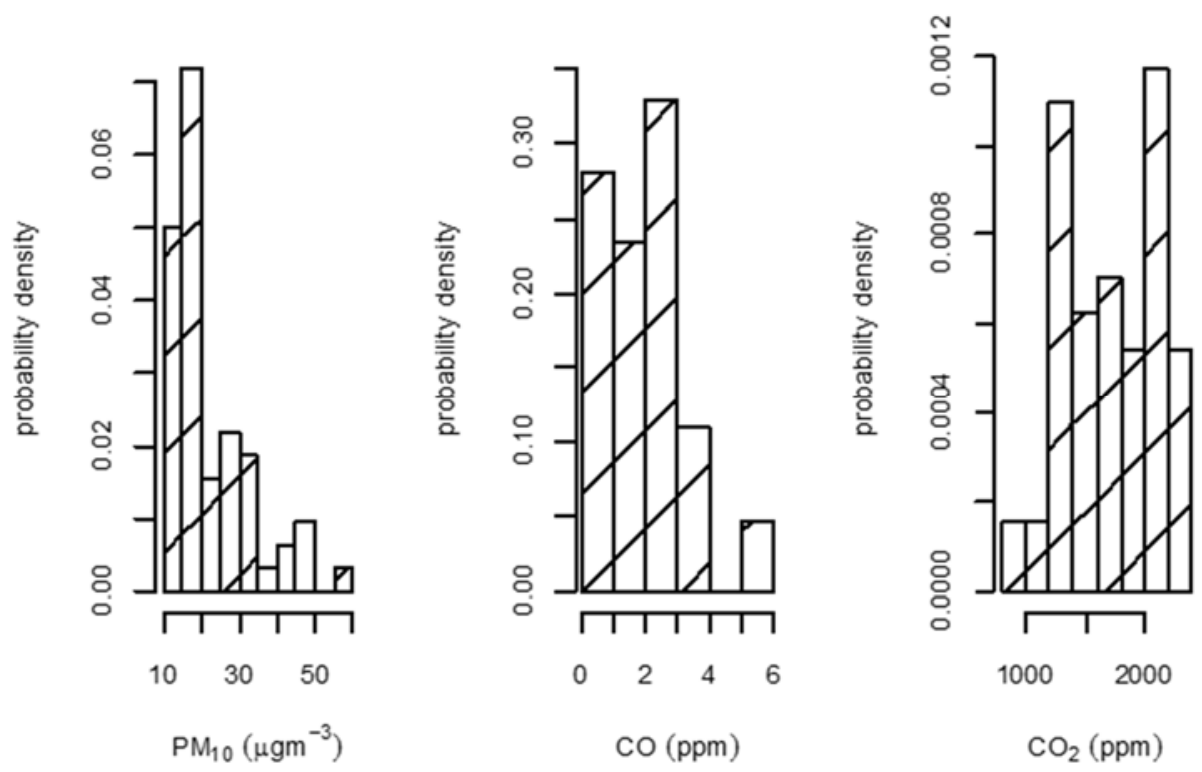

Figure 6: Histograms of $\mathrm{PM}_{10}, \mathrm{CO}$ and $\mathrm{CO}_{2}$ in the library.

Unlike bimodal distributions obtained in previous investigations [18], [23], the $\mathrm{PM}_{10}$ concentration distribution, as a function of particle size, was found to exhibit a log normal distribution in this research work.

\subsection{Calibration model}

The correlation coefficient, between $\mathrm{PM}_{10}$ and particle number of $1 \mu \mathrm{m}\left(p n_{1 \mu \mathrm{m}}\right)$, was observed to be larger for mean values of 10 minutes. This coefficient was computed in 0.98 and 0.93 at the coffee shop and library, respectively. Eqns (3) and (4) show the lineal regression model in order to explain the $\mathrm{PM}_{10}$ average concentration for $10 \mathrm{~min}$ as a function of the particle number of $1 \mu \mathrm{m}$ at the coffee shop and library, respectively.

$$
\begin{aligned}
& \text { C_PM10 }=-34.28273+0.02061 * p n_{1 \mu \mathrm{m}}, \\
& \text { C_PM10 }=-24.02252+0.01793 * p n_{1 \mu \mathrm{m}} .
\end{aligned}
$$

The observed data, the fitted regression models and the predictive intervals for each indoor enclosure can be seen in Figs 7 and 8. Likewise the RMSE statistical values for each model and its comparison with the total average is shown. The RMSE statistical value with the training data was 20.8 at the coffee shop and 4.20 at the library. At this point, it is worth mentioning that such results resulted lower than those RMSE mean values obtained from the test data (21.97 and 4.31 for the coffee shop and library, respectively), indicating that the model was performed properly. However, the coffee shop model overestimated the observed values when the particle number was higher than 12,000 . 

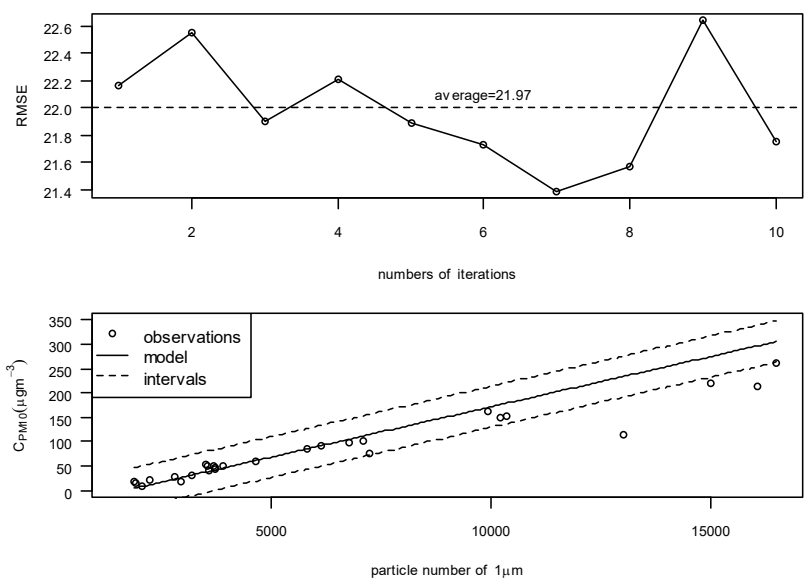

Figure 7: Straight lines of the regression for the coffee shop.

From a previous research work [24], it has been shown that specific variables of categorical type can be reliable for indoor $\mathrm{PM}_{10}$ predictors for both rural and urban regions. In conclusion, they found that cooking activities significantly increased the indoor $\mathrm{PM}_{10}$ concentration, while particle concentration decreased when the windows were opened. In this case, such categorical variables were used as predicting variables in the regression model. Moreover, when the $\mathrm{PM}_{10}$ concentration and outside temperature were included, a value of $\mathrm{R}^{2}<0.6$ was computed. In the current work, these categorical variables were not considered. However, other variables like day time and the day of the week allowed to pinpoint the increase of activities at certain hours and days. Nevertheless, these categorical variables did not explain the variation of indoor $\mathrm{PM}_{10}$ levels. Therefore, it is thought that the type of food and the number of persons attending the indoor places at certain hours become an important variable to be considered. In this concern, the application of artificial neuronal network models can also improve its accuracy in comparison with statistical models [25].

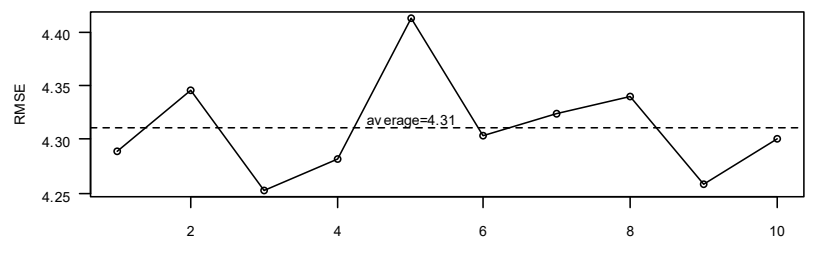

numbers of iterations

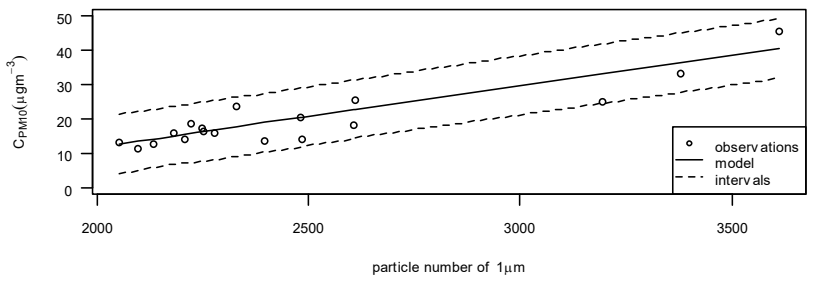

Figure 8: Straight lines of the regression for the library. 


\section{CONCLUSIONS}

The air quality of educational enclosures with high student population has been evaluated. At the coffee shop, the CO levels exceeded the air quality standards established by WHO during the first morning hours when cooking service took place. For both coffee shop and library enclosures, the $\mathrm{PM}_{10}$ concentration levels were satisfactorily modelled. Therefore, the proposed predictive models demonstrated to be effective in order to diminish the number of direct measurements, which are time consuming and costly.

For the studied academic areas, the mean hourly values of $\mathrm{CO}_{2}$ and temperature exceeded the maximum values recommended by ASHRAE as comfort levels. Concerning the relative humidity in the library, values of $60-90 \%$ were recorded exceeding the maximum levels established by ASHRAE. Under similar ambient conditions, the current results revealed that temperature and relative humidity played an important role for bacteria growth in university buildings.

\section{REFERENCES}

[1] Katsoyiannis, A. \& Bogdal, C., Interactions between indoor and outdoor air pollution. Environmental Pollution, 169, pp. 150-151, 2012.

[2] Branco, P.T.B.S., Alvim-Ferraz, M.C.M., Martins, F.G. \& Sousa, S.I.V., Indoor air quality in urban nurseries at Porto city: Particulate matter. Atmospheric Environment, 84, pp. 133-143, 2014.

[3] Silva-Almeida, M., Wolterbeek, H.T. \& Almeida, S.M., Elderly exposure to indoor air pollutants. Atmospheric Environment, 85, pp. 54-63, 2014.

[4] Huixing Li, Chengcheng Tang, Yibo Zhao, Guohui Feng \& Zhiqiang Kang, Measurement and evaluation to the library reading room pollutants. Procedia Engineering, 121, pp. 1836-1843, 2015.

[5] Chen, R., Zhou, B., Kan, H. \& Zhao, B., Associations of particulate air pollution and daily mortality in 16 Chinese cities: An improved effect estimate after accounting for the indoor exposure to particles of outdoor origin. Environmental Pollution, 182, pp. 278-282, 2013.

[6] Vukovic, G., Urosevic, M.A., Razumenic, I., Kuzmanoski, M., Pergal, M., Skrivanj, S. \& Popovic, A., Air quality in urban parking garages (PM10, major and trace elements, PAHs): Instrumental measurements vs. active moss biomonitoring. Atmospheric Environment, 85, pp. 31-40, 2014.

[7] Jafta, N., Barregard, L., Jeena, P.L. \& Naidoo, R.N., Indoor air quality of low and middle income urban households in Durban, South Africa. Environmental Research, 156, pp. 47-56, 2017.

[8] Matías Velázquez, A.A., Exposición a materia particulada y dióxido de carbono en un ambiente universitario en Villahermosa, Tabasco. Revista Mexicana de Agroecosistemas, 3(2), pp. 108-121, 2016.

[9] World Health Organization, Indoor air pollutants: exposure and health effects EURO Reports and Studies No 78. WHO Regional Office for Europe: Copenhagen, 1983.

[10] Congrong, H. Morawska, L., Hitchins, J. \& Gilbert, D., Contribution from indoor sources to particle number and mass concentrations in residential houses. Atmospheric Environment, 38(21), pp. 3405-3415, 2004.

[11] Raiyani, C.V., Characterization and problems of indoor pollution due to cooking stove smoke. Atmospheric Environment, 27A, pp. 1643-1655, 1993.

[12] World Health Organization, Guidelines for Indoor Air Quality: Selected Pollutants. Regional Office for Europe, ISBN 978928900213 4, 2010. 
[13] Barbeau, J., Brisson, C. \& Allaire S., Prevalence of the sick building syndrome symptoms in office workers before and six months and three years after being exposed to a building with an improved ventilation system. Occupational and Environmental Medicine, 54, pp. 49-53, 1997.

[14] Seppanen, O.A., Fisk, W.J. \& Mendell, M.J., Association of ventilation rates and $\mathrm{CO}_{2}$ concentrations with health and other responses in commercial and institutional buildings. Indoor Air, 9, pp. 226-252, 1999.

[15] Righi, E., Aggazzotti, G., Fantuzzi, G., Ciccarese, V. \& Predieri, G., Air quality and well-being perception in subjects attending university libraries in Modena (Italy). The Science of the Total Environment, 286, pp. 41-50, 2002.

[16] Verzani, J., Using $R$ for Introductory Statistics. Chapman \& Hall/CRC Press: Boca Ratón, FL, 2005.

[17] Wallace, L. \& Howard-Reed, C., Continuous monitoring of ultrafine, fine, and coarse particles in a residence for 18 months in 1999-2000. Air \& Waste Management Association, 52, pp. 828-844, 2002.

[18] Seea, S.W. \& Balasubramanian, R., Risk assessment of exposure to indoor aerosols associated with Chinese cooking. Environmental Research, 102, pp. 197-204, 2006.

[19] Shun-Cheng, L., Hai, G., Wai-Ming, L. \& Lo-Yin, C., Inter-comparison of air pollutant concentrations in different indoor environments in Hong Kong. Atmospheric Environment, 36, pp. 1929-1940, 2002.

[20] Sabah, A.-W., Nahed S. \& Sappurd A., Investigation of the environmental indicators at the main library of Sultan Qaboos University (SQU) in the Sultanate of Oman. Sustainable Environmental Research, 25(3), pp. 131-139, 2015.

[21] Gallo, F., Aerobiological research and problems in libraries. Aerobiologia, 9, pp. 117130, 1993.

[22] Shames, S.R., Auweter, S.D. \& Finlay, B.B., Review. Co-evolution and exploitation of host cell signaling pathways by bacterial pathogens. The International Journal of Biochemistry \& Cell Biology, 41(2), pp. 380-389, 2008.

[23] Wallace, L., Emmerich, S.J. \& Howard-Reed, C., Source strengths of ultrafine and fine particles due to cooking with a gas stove. Environmental Science \& Technology, 38, pp. 2304-2311, 2004.

[24] Meier, R. et al., Modeling indoor air pollution of outdoor origin in homes of SAPALDIA subjects in Switzerland. Environment International, 82, pp. 85-91, 2015.

[25] Elbayoumi, M., Ramli, N.A. \& Yusof, N.F.F.M., Development and comparison of regression models and feedforward backpropagation neural network models to predict seasonal indoor $\mathrm{PM}_{2.5-10}$ and $\mathrm{PM}_{2.5}$ concentrations in naturally ventilated schools. Atmospheric Pollution Research, 6, pp. 1013-1102, 2015. 